\title{
Internet resources for grants and foundations
}

\author{
By Hilary Sternberg
}

\section{The Internet way to say "show me the money"}

I

$\mathrm{n}$ a world where information is power, nowhere is this more eviclent than with the identification and solicitation of grant and foundation funding. Whether seeking funds for your library's information literacy program or assisting a development officer find support for a cultural agency, researching foundations and grants is not an easy task. Targeting a financial champion for your project or program takes considerable preparation. The seeker of such financial support must dovetail proposals precisely to the foundation's programmatic requirements. While the competition is keen and the number of funding requests remains high, as many as 80 percent of proposals submitted to private foundations are automatically disqualified. Applications are eliminated because the applicants failed to match their needs with the foundation's stated mission and priorities. ${ }^{1}$ Meticulous research and thoughtful preparation of grant proposals can prove rewarding; after all, foundations are created for the purpose of donating money. In 1995 private foundation giving reached $\$ 10.44$ billion. $^{2}$

Unfortunately, many nonprofit and not-forprofit institutions have been facing stagnant or steadily declining budgets at a time when the need for operational sustenance is greater than ever. Some, weary of this less-is-more environment, have been forced to do less with less, requiring many of the uninitiated to seek outside funds for the first time. Grant monies can supplement many types of critical activities-endowments, capital campaigns, match- ing funds, equipment, fellowships, research, special projects, conferences, and seminars. Most successful grants request underwriting for specific activities which have a finite support period, thus confining the funder's commitment.

The Internet encompasses an exciting galaxy of foundation information and a variety of funding resources for both the neophyte and the experienced grant researcher. Foundation sites contain keys to programmatic giving, geographic focus, range of grant awards, program and support limitations. Additional information provides networking opportunities with colleagues, grant-writing structure and methodology, and access to professional literature. Many associations and government agencies, as well as corporate, private, and community foundations maintain a Web presence on the Internet. Of course, with the ever-changing nature of the Internet no article could provide a permanently comprehensive list of resources. Be aware that some sites with multiple points of access will have overlapping information and links. The following selected sites are intended to provide an introduction to the subject of grants and foundations. Explore the sites, peruse an e-journal, and enjoy surfing the links.

\section{Best starting places/megasources}

- CARDE's Other Grant and Funding Pages on the Web. Produced by the Center for Applied Research and Development in Education at the University of Texas at Austin, this site has links to fecteral and private sector grants, general resources for grantseekers, and resources for grantwriters and graduate fellowships. Access: 1http://edb518g.edb.utexas.edu/ www_server/hotlist.html. 
- Charity Village. Bilingual links to Canadian and U.S. sites for nonprofit organizations, professional associations, online resources, funding sources, research, news, and more. Select "The Bus Station." Access: http:// Www.charityvillage.com/charityvillage/.

- Community of Science Funding Opportunities. A boolean searchable, international database that includes fecleral agencies, private foundations, state and provincial organizations, commercial entities, nonprofit organizations, professional associations, and academic institutions. Contrary to what the title might suggest, this site also includes some sources for arts and humanities, education, engineering, law, and others. Access: http:// cos.gdb.org/repos/fund/fund-intro.html.

- Financial Aid Information PageGrant Information. Sponsored by the $\mathrm{Na}$ tional Association of Student Financial Aid Administrators, this site includes links to indexes of grant information, grantowriting, grant clatabase, periodicals, government grants, and grantrelated sources. Access: http://www.finaid.org/ finaid/awards/grants.html.

- Nonprofit Resources Catalogue: Fundraising and Giving. Award-winning site developed by Phillip $A$. Walker with more than 200 links which include funding sources, foundations, and corporate contributions. Updated monthly. Access: http://www.clark net/pub/ pwalker/Fundraising_and_Giving/.

\section{Organizations}

- Council on Foundations. A nonprofit coalition of grantmaking foundations and corporations whose goal is to promote responsible and effective philanthropy. This site includes Foundation News and Commentary and Council Columns Newsletter, publications of books and videos, general information on foundations, how to start a foundation, legislative and public policy watch, and foundation homepages. Access: http://www.cof.org.

- Foundation Center. This site provides grantmaker information, funding trends and analysis, Pbilantbropy News Digest, training and seminars, libraries and locations, fundraising process, Foundation Center publications, and a list of cooperating libraries. There are annotated searchable links to more than 160 private, community, and corporate foundations, plus federal grants and public charities. Also ranks foundations by assets and total giving. An online librarian is available to answer your e-mail questions. Access: http:// fdncenter.org/.

- The Grantsmanship Center. TGC is known for its grants and fundraising seminars. A list of its excellent print publications--each. available for $\$ 3$ to $\$ 4$-and an order form are provided. Also included in this site are nonprofit resources, TGC Magazine, today's Federal Register grant information, and links to grantmaking foundations-arts, community, corporate, international, private foundations, and public charities. Access: http://www.tgci. $\mathrm{com} /$.

\section{Directories}

- Foundations On-Line: A Directory of Charitable Grantmakers. Sponsored by the Northern California Community Foundation, this site has alphabetical directories of foundations and fundraising events plus information on fundraising software, consultants, products, etc. Access: http://www foundations.org

\section{- IAN Web Resources: Grant Opportu-} nities. Alphabetical links to individual foundations, organizations, and grant collections. Some listings have full or partial text. Access: http://www.pitt.edu/ ian/resource/grants.htm.

- U.S. Foundations and Fundraising Coalitions Resources. Links to organizations, foundations, publications, guides, and directories. Access: http://www.contact.org/usfound. htm.

\section{Government funding}

- Federal Information Exchange, Inc. A searchable database of current federal funding from twelve government agencies: Departments of Energy, Agriculture, Transportation, and Veterans Affairs, Air Force Office of Scientific Research, NASA, National Institute of Health, Office of Naval Research, Agency for International Development, Defense Information Systems Agency, the Interagency Learning Technology Office, Defense Information Systems Agency-Office of the Chief Information Office-Educational Institutional Partnership Program. Includes a free daily online e-mail ser vice which provides notification of targeted research and education grants in areas specified by the user's profile. Access: http:// www.fie.com/fedix/.

- Federal Register Online via GPO Access. The Federal Register, as the official publication for presidential documents, executive orders, notices, rules, and proposed rules from 
federal agencies, will provide the first published notification for federal grants. This database is searchable using boolean operators from 1995 to the present. Access: http://www.access. gpo.gov/su_docs/aces/aces140.html.

- Federally Funded Research in the U.S. This site provides links to the National Institutes of Health, National Science Foundation, Small Business Innovation Research, Department of Agriculture, and the Advanced Technology Program. Access: http://medoc.gdb.org/ best/fed-fund.html.

- Grants and Awards. This U.S. Government grants site includes a searchable Catalog of Federal Domestic Assistance - the most comprehensive listing of federal grants from government agencies. There are links to 25 government sites. Access: http://www access. gpo.gov/su_docs/dpos/topics/grants.html.

- Money Matters. Links are provided to the Guide to U.S. Education Programs, What Should I Know About ED Grants?, and GCS Web, which provides information about current contract and grant opportunities and stuclent financial assistance. Access: http:// www.ed.gov/money.html.

- TRAM Research Funding Opportunities and Administration. From the Texas Research Administrators Group, which contains unusual tools and types of information including electronic downloadable forms in Mac and $\mathrm{PC}$ versions for several government agencies and foundations, links to federal regulations and guidelines to several government agencies, a search engine for research opportunities and funding sources, links to sample policies and agreements contributed by universities and organizations, and links to additional servers. Access: http://tram.rice.edu/TRAM/index.html.

\section{Reception time changed}

The time for the ACRL Academic/Research Librarian of the Year Award Reception at the ALA Annual Conference in San Francisco has been changed to 5:00-6:30 p.m., Monday, June 30. Feel free to join ACRL at this reception as it honors James G. Neal, director of libraries at Johns Hopkins University, as its 1997 Academic/Research Librarian of the Year. For more information on the 1997 award winners see page 337 of this issue.

\section{Grant writing}

- Corporate and Foundation Funding. Dick Olsen and Chris Murray of the University of Southern California provide examples of an introductory letter and proposal to a foundation. An outline for effective proposal writing takes the guesswork out of this process. Includes a step-by-step methodology for securing corporate support and foundation funding. Access: gopher://cwis.usc.edu/11/Library Research/Research/Funding.

- How to Write Successful Grant Proposals. The full text of three successful grant proposals are posted here, as well as shareware and freeware applications to make grant writing easier. Access: http://ipt.lpl.arizona.edu/ IPT/Grant/

- Proposal Development. Written by the Pennsylvania State University Research and Technology Transfer Organization, this site includes a reprint portion of Proposal Development Handbook written by Dean Kleinert and Libby Costello of the Office of Federal Programs. It explains how to develop a statement of need, goals and objectives, methodology, budget and proposal elements. In addition there is identification of funding opportunities and a bibliography of print sources. Access: http:// infoserv.rttonet.psu.edu/spa/fac-guid.htm\#pd.

- A Proposal Writing Short Course. An excellent how-to guide that defines proposal structure. It is excerpted from Guide to Proposal Writing, revised edition, written by Janice C. Geever and Patricia McNeill and published by the Foundation Center in 1997. Provides recommendations for additional reading. Access: http://fdncenter.org/2fundpro/ 2prop.html.

- Tips for Success. Created by Rebecca Ryan and Howard Kaplan of Georgia Southern University from their workshop Nuts and Bolts: An Introduction to Grant Development. The authors discuss developing contracts, boilerplate proposals, following guidelines, dissemination plans, reviewer's comments, and more. Access: gopher://eagle1.cc.GaSoU.edu: $70 / 00 /$ Georgia $\% 20$ Southern $\% 20$ University Office $\% 20$ of $\% 20$ Research $/$ Tips $\% 20$ for $\% 20$ Success.

\section{Electronic journals/magazines}

- The Chronicle of Higher EducationAcademe This Week. This segment of the Chronicle provides deadline and contact information for grants, fellowships, papers, and ex- 
change programs, as well as other information. With few exceptions, the deadlines are so current that it is too late to apply this year, but now there is an entire year to think about a project for next year's deadline. Access: http:// www.chronicle.merit.edu/.events/.links.html.

- Council Columns Newsletter. Selected full-text articles from the Council on Foundation's print newsletter Council Columns. Nineteen issues per year. Access: http:// www.cof.org/columns/.

- Foundation News and Commentary. A bimonthly periodical published by the Council on Foundations, which lists a table of contents for the last three issues and includes two or more full-text articles per issue. Access: http:/ /www.cof.org/fnc/.

- The Grantsmansbip Center Magazine. Full text of fall 1995, spring 1996, summer 1996, and winter 1997 print issues. Access: http://www.tgci.com/publications/pub.htm.

- Pbilantbropy Journal Alert. Free e-mail newsletter providing up-to-the-minute news in the nonprofit sector and new developments at the Web site. Access: http://www. philanthropy-journal.org/todo/pjalert.htm.

- Pbilantbropy Journal Online. "All the Nonprofit News That's Fit to Hit." A nonprofit newspaper providing news and information regarding the nonprofit sector including numerous links and resources available on the Web. Access: http://www.philanthropy-joumal.org/.

- Pbilantbropy News Digest. A Foundation Center weekly publication whose articles are gleaned from newspapers and wire services relating to philanthropy. Many articles have "FC" annotated notes which provide background information. Full text is provided for the past eight weeks. Access to the archives is through a search engine. In addition, there is a searchable donor, officer, and trustee index. Access. http://fdncenter.org/phil/philmain.html.

\section{Other interesting sites}

- Fundraising. A bibliography of print sources in fundraising. Citations are for works published in 1995 or earlier. Many are of the "how to" variety for finding information on grants and foundations and grantwriting methodology. Access: http://www.iupui.edu/it/ philanth/bigbib.html\#FUNDRAISING.

- Payton Philanthropic Studies Library. The library provides links to foundations, nonprofits, grant information, and electronic journals. An online searchable version of the Pbilantbropic Studies Index (1991-1994) provides access to book and periodic literature on volunteerism, nonprofit organizations, fundraising, and charitable giving. Information is included for the fundraising school, school degree programs, applied research, and more. Access: http://www-lib.iupui.edu/philanthropy/ payton.html.

- University of Idaho Education Grants Directory. Links to sites recommended by James Kearney in The Grant Getter's Guide to the Internet, which include federal grant sources, foundations and private grant sources, grant directories, and education resources. $A c$ cess: http://radon.chem.uidaho.edu/ pmits/ grants/homepage.html.

\section{Notes}

1. Annual Register of Grant Support: $A D i-$ rectory of Funding Sources, 30th ed. (New Providence, N.J.: R. R. Bowker, 1997), vii.

2. Giving USA (New York: American Association of Fund-Raising Counsel, 1996), 12.

\section{Grant funding and distribution by major subject categories, 1995}

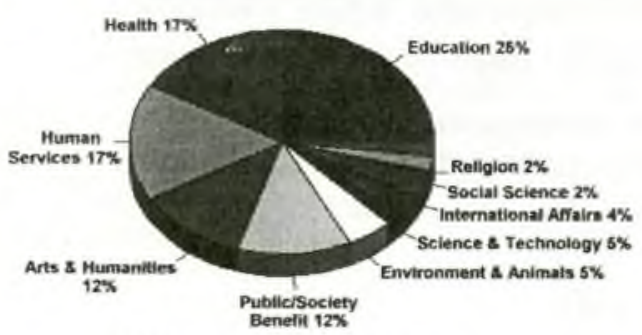

Percent of Grant Dollars

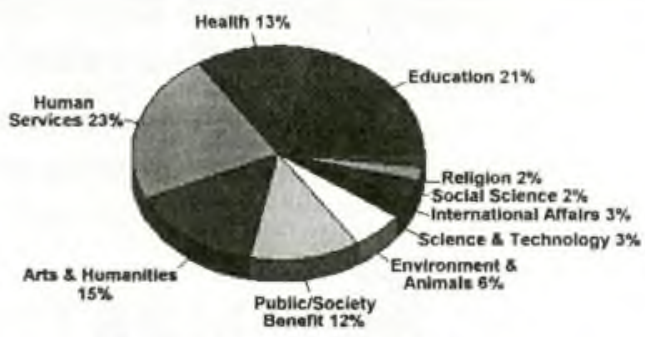

Percent of Number of Grants 

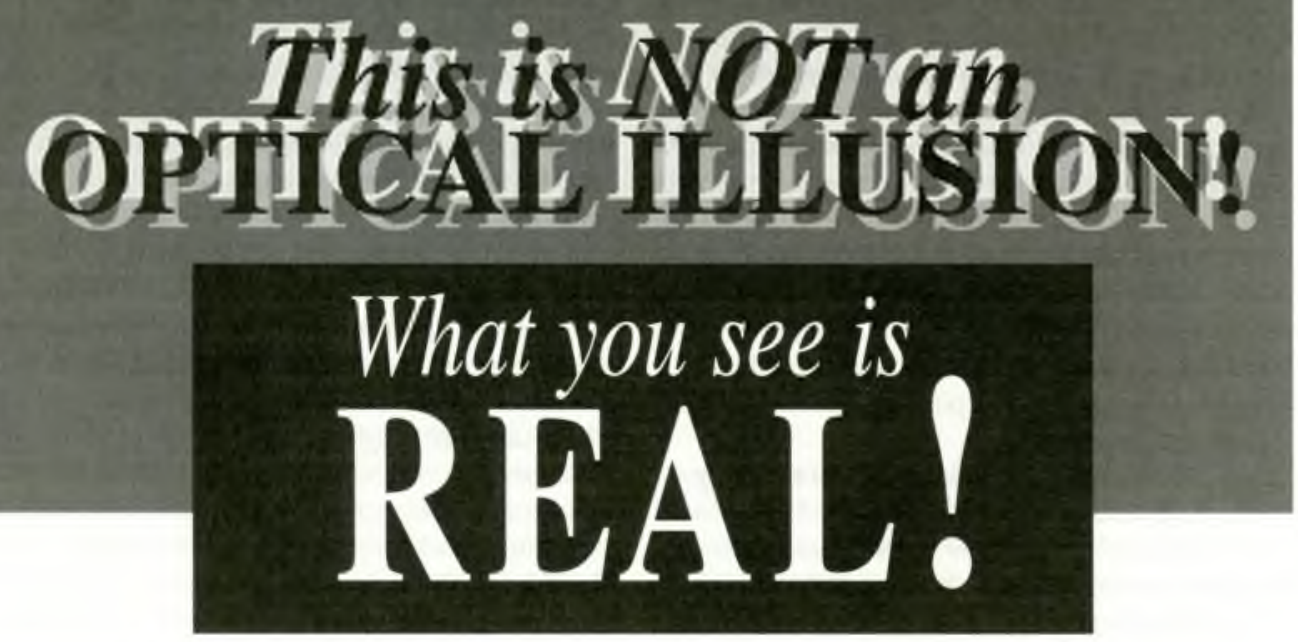

Today, when you place your academic firm orders with Baker \& Taylor you can receive...

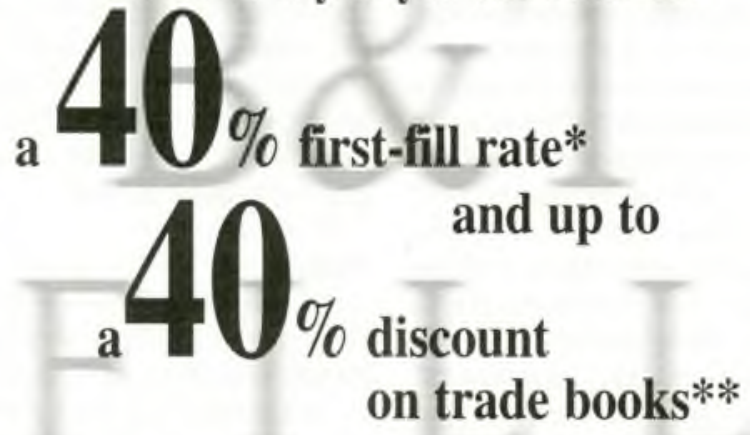

It's plain to see why you should call Baker \& Taylor, the \#1 Domestic Firm Order Supplier for Academic Libraries. Talk to your Sales Representative today and see for yourself that we're focused on a clearly visible improvement in service!

To set up an account or for sales representative information,

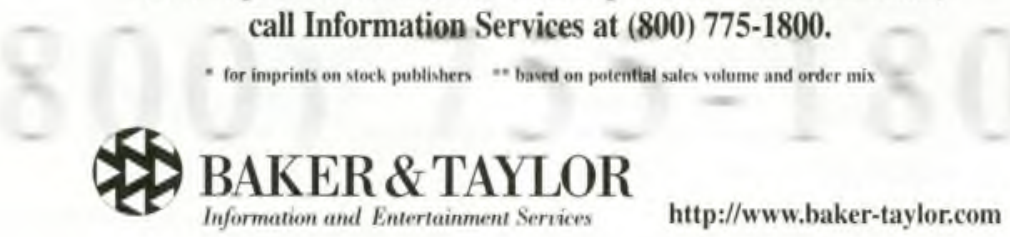

